\title{
INTERPRETASI STRUKTUR BAWAH PERMUKAAN GUNUNG MURIA MENGGUNAKAN ANALISA DATA GRAVITASI
}

\author{
Nasrun Balulu*
}

\begin{abstract}
A geophysical survey using gravity method was carried out in Muria volcano. This research aimed to interpret the subsurface geology condition of the research area based on gravity data analysis. Research area is $\left(47,6\right.$ x 45) $\mathrm{km}^{2}$ with 222 observation points. Gravitymeter LaCoste \& Romberg type G-1118 MVR was used to measure the gravity field, and differential method of Global Positioning System (GPS) was used to measure the position and elevation.
\end{abstract}

Data processing was performed to gain complete Bouguer anomaly of both residual and regional. Bouguer density using graphical method resulted to the value of $2.67 \mathrm{gr} / \mathrm{cm} 3$. Transformation to a horizontal plane was performed obtain by using equivalent mass method with horizontal level's height of 1602 meters beyond the spheroid reference and equivalent The separation of regional anomaly and residual anomaly was generated through upward continuation method and resulted to regional anomaly in the height of 15000 meters up the spheroid reference. The residual anomaly acquired by subtract the regional anomaly toward the complete Bouguer anomaly in a horizontal plane.

The subsurface modelling of Muria volcano and its surrounding was acquired from Grav2DC for Windows. The result shows that Muria volcano and its surrounding was regionally controlled by rock resulted from volcanic processes as lava (density $2,91 \mathrm{gr} / \mathrm{cm} 3$ ). This volcanic rock due to the gravity collapse performed a caldera filled by andesit (density $2,58 \mathrm{gr} / \mathrm{cm} 3$ ). Another rock which is deposited in Muria volcano are tuff from Muria Tuff (density 2,4 $\mathrm{gr} / \mathrm{cm}^{3}$ ), tuff sandstone from Patiayam formation (density 2,5 gr/ $\mathrm{cm}^{3}$ ), limestone from Bulu formation (density $2,7 \mathrm{gr} / \mathrm{cm}^{3}$ ), and limestone from Ngrayong formation (density $2,8 \mathrm{gr} / \mathrm{cm}^{3}$ ).

Keywords:Bouguer anomaly, Regional anomaly, Residual anomaly, Modeling, Subsurface stracture.

\section{PENDAHULUAN}

Gunungapi Muria dan sekitarnya terletak di semenanjung Muria, sebelah timurlaut Semarang, ibukota propinsi Jawa Tengah. Morfologi daerah penelitian berupa gunung dengan ketinggian maksimal 1602 meter di atas permukaan laut (McBirney, et al., 2003). Gunung api Muria berada di empat kabupaten yaitu kabupaten Kudus, Jepara, Pati dan Rembang

Gunung muria merupakan salah satu gunung api di pulau Jawa yang berhubungan dengan subduksi yang berumur Miosen, bukun merupakan subduksi aktif hal ini berbeda dengan gunung api di pulau jawa lainnya yang secara umum berhubungan dengan subduksi sekarang (subduksi aktif). Penelitian yang selama ini dilakukan di

*) Program Studi Pendidikan Fisika Jurusan Pendidikan Matematika dan Ilmu Pengetahuan Alam Fakultas Keguruan dan Ilmu Pendidikan Universitas Khairun Ternate 
semenanjung Muria hanya sebatas pada permukaan saja seperti penelitian kimiawi air kawah, sejarah geologi, sedangkan metode sismik yang digunakan adalah metode sismik dengan data gempa mikro, hasilnya menyatakan bahwa indikasi gempa yang direkam selama periode pengukuran Desember 1994-Februari 1995 disebabkan oleh aktifitas tektonik (bukan merupakan aktivitas volkanik Gunung Muria). Hasil identifikasi struktur geologi bawah permukaan Gunung Muria dan sekitarnya dengan mengunakan metode gravitasi dan magnetik, menyatakan bahwa struktur bawah permukaan Gunung Muria tidak terlalu kompleks. Serta melakukan pengukuran gradien suhu, hasilnya bahwa masih aktifnya aktifitas magmatik di bawah Gunung Muria berdasarkan pemetaan gradien suhu di semenanjung muria (National Technical Team 2000).

Penelitian ini dilakukan untuk mempertajam analisa dari penelitian-penelitian terdahulu, disamping adanya peningkatan aktivitas tektonik di Semenanjung Muria.

\section{METODE PENELITIAN}

\section{Lokasi Penelitian}

Lokasi penelitian mencakup semenanjung gunung api Muria yang meliputi daerah seluas (47,6 x 45) $\mathrm{km}^{2}$. Daerah penelitian ini secara administratif terletak di tiga kabupaten yaitu kabupaten Jepara, Pati dan Kudus (gambar 3). Batas-batas daerah penelitian adalah $6^{\circ} 24^{\prime} 14,63^{\prime \prime}$ LS - 6 $48^{\prime} 06,37^{\prime \prime}$ LS dan 110³8'47,27" BT $111^{\circ} 04^{\prime} 15,29 "$ BT.

\section{Peralatan yang Digunakan}

Alat-alat yang digunakan dalam penelitian adalah :

1. Gravitymeter LaCoste \& Romberg tipe G-1118 MVR yang dilengkapi dengan sistem umpan balik elektronik (Internal Feedback System).

2. Global Positioning System (GPS) Trimble Navigation 4600 LS dengan ketelitian $10 \mathrm{~cm}$.

\section{Pengolahan Data}

Pengolahan data gravitasi meliputi konversi ke miligal, koreksi tinggi alat, koreksi drift, koreksi pasan surut, koreksi gravitasi normal, koreksi udara bebas, koreksi Bouguer, koreksi medan, proyeksi ke bidang datar tertentu, pemisahan anomali residual-regianal, pemodelan dan interpretasi(Imam Suyanto, Kirbani, S.B., 1999).

Metode yang dipakai dalam penelitian ini adalah metode gravitasi yang merupakan salah satu metode pasif geofisika untuk mencari anomali bawah permukaan. 


\section{Interpretasi Data}

Interpretasi data dalam metode gravitasi digunakan dua kuantitatif dilakukan dengan pemodelan, yaitu pembuatan model benda geologi atau struktur bawah permukaan dari respon yang berasal dari medan gravitasi daerah penelitian. Lintasan model yang diambil tepat berada di puncak atau sekitar puncak Muria. Sedangkan untuk interpretasi kualitatif dilakukan dengan cara menafsirkan peta kontur anomali Bouguer lengkap baik lokal maupun regional dengan hasil program yang diperoleh.

\section{HASIL}

Dari data sayatan geologi diperoleh 5 jenis batuan yang terdapat di daerah penelitian. Dari hasil permodelan didapat enam buah poligon dengan tingkat kesalahan antara $0.58 \%$ hingga $0.98 \%$.

Poligon batuan berwarna putih kecoklatan dengan massa jenis $2.4 \mathrm{gr} / \mathrm{cm}^{3}$ diinterpretasikan sebagai densitas tuf, berwarna merah dengan massa jenis $2.58 \mathrm{gr} / \mathrm{cm}^{3}$ yang diinterpretasikan sebagai densitas batuan andesit, berwarna merah tua memiliki massa jenis $2.91 \mathrm{gr} / \mathrm{cm}^{3}$, yang diinterpretasikan sebagai lava. berwarna kuning memiliki massa jenis $2.5 \mathrm{gr} / \mathrm{cm}^{3}$, diinterpretasikan sebagai batupasir tufaan, berwarna hijau muda memiliki massa jenis $2.7 \mathrm{gr} / \mathrm{cm}^{3}$, yang diinterpretasikan sebagai batugamping. Dan poligon berwarna hijau tua memiliki massa jenis $2.8 \mathrm{gr} / \mathrm{cm}^{3}$, diinterpretasikan sebagai batulempung.

\section{PEMBAHASAN}

Lava dari satuan batuan Lava Muria yang mempunyai densitas $2,91 \mathrm{gr} / \mathrm{cm}^{3} \mathrm{di}$ daerah penelitian merupakan batuan hasil dari proses vulkanik yang terjadi di Gunung Muria. Lava dari satuan batuan Lava Muria ini mempunyai densitas yang lebih tinggi dibandingkan dengan nilai densitas Bouguernya (mempunyai kontras densitas positif). Lava ini mengintrusi batugamping dari formasi Bulu, batupasir tufaan dari formasi Patiayam.

Jenis batuan paling tua yang diinterpretasikan adalah batu lempung dari formasi Ngrayong yang memiliki densitas $2,8 \mathrm{gr} / \mathrm{cm}^{3}$. Batu gamping dari formasi Bulu dengan densitas 2,7 $\mathrm{gr} / \mathrm{cm}^{3}$ dan batu pasir tufaan dari formasi Patiayam dengan densitas 2,5 $\mathrm{gr} / \mathrm{cm}^{3}$ diendapkan di atas batu lempung formasi Ngrayong. Urut-urutan umur batuan ini didasarkan pada data geologi berupa tatanan stratigrafi di daerah penelitian. Ketiga jenis batuan tersebut mempunyai nilai kontras densitas yang negatif.

Tuf dari satuan batuan Tufa Muria terendapkan paling atas di daerah penelitian. Penyebaran tuf ini mengelilingi daerah di sekitar Gunung Muria tetapi ketebalannya tidak terlalu besar. Densitas tuf dari satuan batuan Tuf Muria adalah 2,4 gr/ $\mathrm{cm}^{3}$. 


\section{KESIMPULAN}

Kesimpulan yang diperoleh dari hasil pengolahan data dan interpretasi data pada penelitian metode gravitasi di Gunung Muria dan sekitarnya ini adalah :

Kondisi geologi bawah permukaan Gunung Muria dan sekitarnya secara lokal, dikontrol oleh batuan hasil proses vulkanik yang mengalami robohan gravitasi sehingga membentuk kaldera yang terisi oleh batuan andesit yang mempunyai densitas 2,58 $\mathrm{gr} / \mathrm{cm}^{3}$. Batuan penyusun Gunungapi Muria dan sekitarnya terdiri dari batuan andesit yang mempunyai densitas $2,58 \mathrm{gr} / \mathrm{cm}^{3}$ dan lava yang mempunyai densitas $2,91 \mathrm{gr} / \mathrm{cm}^{3}$ dari satuan batuan Lava Muria.

\section{DAFTAR PUSTAKA}

Imam Suyanto, Kirbani, S.B., 1999, Pembuatan Titik Ikat Baru dan Uji Kalibrasi Jalur Bandung-Tangkuban Perahu, Pertemuan Ilmiah HAGI 1999, Surabaya.

McBirney, A.R., Serva, L., Guerra, M., and Connor, C.B., 2003, Volcanic and Seismic Hazard at a Proposed Nuclear Power Site in Central Java, Journal of Volcanology and Geothermal Research, Vol. 126, P. 11-30.

National Technical Team, 2000, Feasibility Study on Nuclear Power Plant at Muria Peninsula, Central Java, Indonesia : Final Report on Volcanology, National Technical Team collaboration with National Nuclear Energy Agency, Jakarta. 